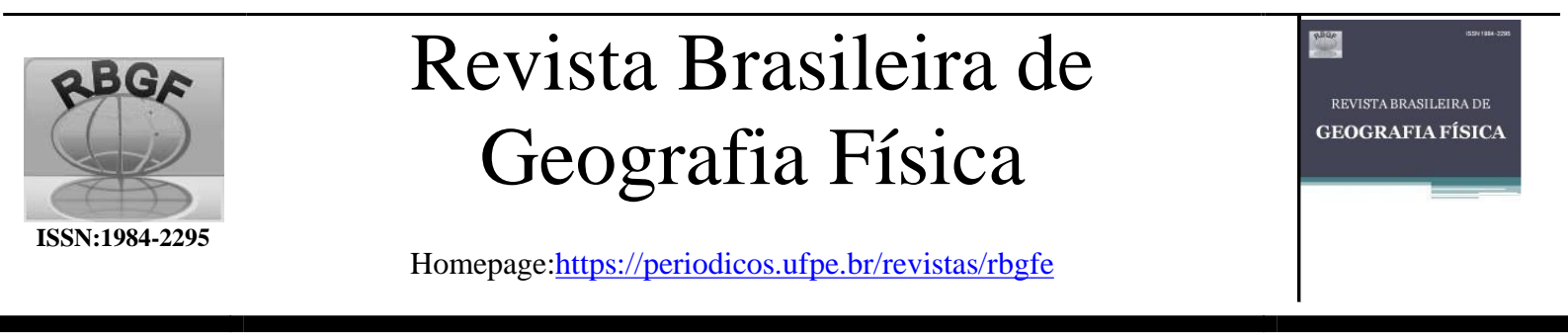

\title{
A Contribution to the Understanding of the Changes in the Profile of the Informal Recycling Market Caused by the Closure of Large Dumpsites: a Case Study from Brazil
}

\author{
Silvanda Galvão Arruda ${ }^{1}$, José Mariano de Sá Aragão ${ }^{2}$, Maisa Mendonça Silva ${ }^{3}$, Sandro Valença ${ }^{4}$, Simone \\ Machado Santos 5
}

${ }^{1}$ Mestre pelo Programa de Pós-Graduação em Engenharia Civil e Ambiental, da Universidade Federal de Pernambuco (UFPE), Caruaru-PE. E-mail: silvanda.galvao@gmail.com. ${ }^{2}$ Docente do Departamento de Engenharia Civil, da Universidade Federal de Pernambuco (UFPE), Recife-PE. E-mail: marianoaragao@gmail.com. ${ }^{3}$ Docente do Departamento de Engenharia de Produção, da Universidade Federal de Pernambuco (UFPE), Recife-PE. E-mail: maisa.ufpe@ yahoo.com.br. ${ }^{4}$ Docente do Núcleo de Gestão, da Universidade Federal de Pernambuco (UFPE), Caruaru-PE. E-mail: sandro_valenca@ hotmail.com. ${ }^{5}$ Docente do Programa de Pós-Graduação em Engenharia Civil e Ambiental (Caruaru-PE) e do Programa de PósGraduação em Desenvolvimento e Meio Ambiente (Recife-PE), da Universidade Federal de Pernambuco. Email:smachados@hotmail.com.

Artigo recebido em 01/05/2020 e aceito em 29/07/2020

\section{R E S U M O}

A separação de resíduos sólidos, como fonte de subsistência, nas ruas ou lixões, ainda é uma realidade em países em desenvolvimento, como o Brasil. A gestão de resíduos sólidos (GRS), quando não planejada de forma integrada, inevitavelmente, afeta o elo mais frágil dessa cadeia os - catadores. Na Região Metropolitana do Recife (RMR), o encerramento dos lixões da Muribeca e de Aguazinha, na última década, desmobilizou um contingente estimado de 1300 catadores. Adicionalmente, nenhum estudo prévio sobre os possíveis efeitos do fechamento desses lixões sobre mercado informal de reciclagem foi realizado. Nesse contexto, este estudo teve como objetivo fornecer suporte ao entendimento da situação atual dos catadores, propondo medidas que possam auxiliar na integração do mercado informal de reciclagem à GRS municipal, após o fechamento dos lixões. Por meio da utilização de questionários estruturados como ferramenta de pesquisa, os resultados obtidos neste estudo delineiam um perfil dos catadores de resíduos em relação à idade, renda e forma de trabalho, além de mostrar um panorama geral sobre o mercado informal de reciclagem.

Palavras-chave: Catadores; Mercado informal de reciclagem; Cooperativas; Integração; Gestão de resíduos sólidos; Países em desenvolvimento.

\section{A B S T R A C T}

Waste picking, as a source of subsistence, whether in the street or in open dumpsites, is still a reality in developing countries, such as Brazil. Solid waste management, if not planned in an integrated way, inevitably affects the most fragile links in the chain of such management- the waste pickers. In the Recife Metropolitan Region (RMR), the closure of the Muribeca and Aguazinha dumpsites in the last decade disrupted a contingent of waste pickers, which was estimated to consist of more than 1300 people. In addition, no previous and consolidated study took place about the effects of the closure of those dumpsites on the informal recycling market. In this context, this work aims to provide support to understand waste pickers' current situation and proposes measures that can result in the informal recycling market's official integration after the closure of the dumpsites. Using the structured questionnaires as an interview tool, the results obtained in this study reveal the profile of the waste pickers, including age, income, and employment, as well as an overall profile of the informal recycling market.

Keywords: Waste pickers; Informal recycling market; Cooperative; Integration; Waste management; Developing countries. 


\section{Introduction}

The Brazilian National Policy for Solid Waste (NPSW), established by Law 12.305/2010 (Brasil, 2010), aims to eliminate and remediate dumpsites and to provide the social and economic inclusion of waste pickers. Before and after the issuance of the NPSW, some large dumpsites were closed in Brazil, including the Aguazinha (municipality of Olinda) and Muribeca (municipality of Jaboatão dos Guararapes) sites located in the Recife Metropolitan Region (RMR) in northeast Brazil. The Aguazinha and Muribeca dumpsites (Figure 1) operated for more than two decades, absorbing a combined rough estimate of 3000 tons of solid waste per day (coming from three municipalities: Recife, Jaboatão dos Guararapes, and Olinda), and were closed in 2010 and 2009 , respectively, by court order.

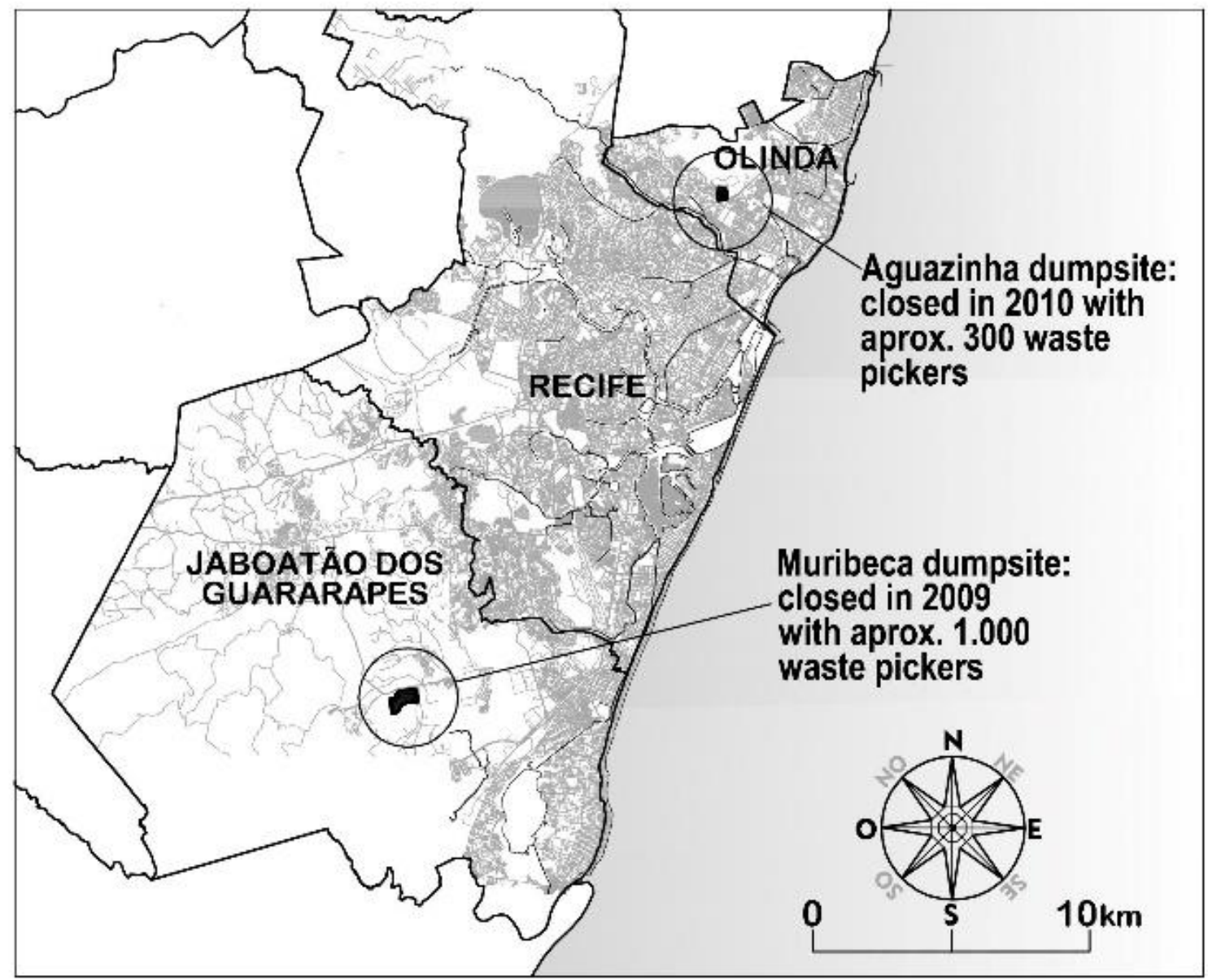

Figure 1. Location of the two dumpsites.

Throughout their life cycle, both dumpsites received financial resources for projects to improve their operational quality standards. However, the two dumpsites never reached adequate sanitary conditions due to, among other reasons, the lack of infrastructure and many waste pickers at the landfill acting without any type of supervision. According to Olinda's solid waste management plan (Vector, 2004), 302 waste pickers worked on the Aguazinha dumpsite. Despite the presence of the waste pickers at the dumpsite, the municipality of Olinda had already prohibited the presence of children among them.

The number of waste pickers working in the Muribeca dumpsite has always been quite controversial. The environmental impact assessment of a private landfill (CTR Candeias), located near the Muribeca dumpsite, mentions the presence of approximately 1000 waste pickers and many waste trader points in the dumpsite's neighborhood (AMS/SA Paulista, 2005). Previously, Melo (2001), citing a registry of the government of Recife, mentioned a contingent of 914 waste pickers; $14 \%$ of them were children and adolescents. Officially, a term of adjustment of conduct, signed between the State Public Ministry and the municipality of Recife, indicated that 860 waste pickers were removed from the Muribeca dumpsite when it was closed (Câmara Municipal do Recife, 2014).

Much of the imprecision in the data regarding waste pickers is a result of little knowledge about waste-picking activity. Generally, waste pickers also suffer from 
Revista Brasileira de Geografia Física, Vol. 13, n. 05 (2020) 1953-1969.

widespread discrimination by society and public authorities. Only those with little or no professional qualifications or those who have few work opportunities are willing to pick through waste. Waste picking is associated with a lack of hygiene, unemployment, and criminal activities, which leads to discriminatory behaviors (Sembiring and Nitivattananon, 2010). Most often, waste pickers are socially excluded and exposed to different vulnerabilities such as occupational health risks and accidents (Uddin et al., 2020). Social acceptance of scavenging is so low that, in some cities, people see it as a threat that should be banned (Nas and Jaffe, 2004; Afon, 2007; Adama, 2012; Oguntoyinbo, 2012). Faced with this negative perception, few people have the courage to call themselves waste pickers.

Although the work in cooperatives and associations provides better organization for scavenging activities, the waste pickers did not generally adhere to the cooperative model in the RMR, even when the dumpsites were functioning. In Brazil, cooperatives and associations are regulated by specific legislation. The legal authorization of a cooperative/association's operation is performed by the respective federal executive body of control, which evaluates the cooperative's resolution and the existence of operating conditions. The resolution must include the following information: (i) the name of the entity and its location and object of operation, (ii) the personal information of the members and founders, (iii) the value and number of the share of each member, and (iv) the cooperative's statute (Brasil, 1971). In cooperatives, workers are not employees but partners; the philosophy of work is solidarity economy, and profits are shared among all members. However, the operation must obey the regiment that regulates schedules and other responsibilities, and this is one of the concerns about the participation of waste pickers in cooperatives and associations, as discussed in the following sections. Olinda's solid waste management plan already mentioned that of the 302 waste pickers working in the dumpsite, only 40 were associated with the Olinda Recycling Association (Vector, 2004). At the Muribeca dumpsite, the situation was quite similar: only 60 waste pickers were members of the Muribeca Collectors Association in 2005 (AMS/SA PAULISTA, 2005).

Following the dumpsites' closure, waste pickers were prohibited from entering and working at waste disposal sites. This was done without a plan being implemented for their insertion into the labor market to minimize the impacts of such a change on their lives. One of the main concerns of managers and human rights entities was the situation that the waste pickers faced after the dumpsites were closed. To help waste pickers survive without dumpsite scavenging, the municipal governments have urged the urban cleaning companies that provide services to the municipality to develop measures to integrate the waste pickers into the labor market in or out of solid waste management (SWM). Nevertheless, these actions are limited, and not all waste pickers were covered. Lastly, in the RMR, waste pickers have been mainly working on the streets or in cooperatives; some cooperatives are supported by municipal governments. This support consists of providing recyclables from selective collection pilot programs, loaning waste segregation areas, and providing training courses (notions of management, cooperativism, and environmental education, among others).

Based on a case study, this article aims to contribute to the understanding of the changes in the profile of the informal recycling market after the closure of two important dumpsites in northeast Brazil. The hypothesis considered in this research was that the closure of the two dumpsites impacted the informal recycling market, especially the routine of waste pickers.

The article is organized in five sections. Section 1 ("Introduction") provides a background on the problems the closure of two major dumpsites caused and their possible impacts as a consequence of the implementation of a new policy for the SWM. Section 2 ("Literature Review") gives a brief evaluation of previous research about the informal recycling market and its stakeholders. Section 3 presents the materials and methods used in the research. Section 4 explores the results using relevant discussions, and Section 5 is dedicated to the conclusion.

\section{Literature Review}

Waste Pickers and the Informal Recycling Market In developing countries, waste pickers play an important and positive role in SWM (Medina, 2000; Sembiring and Nitivattananon, 2010; Asim et al., 2012). In China, the informal sector is estimated to be responsible for supplying about 17$38 \mathrm{w} / \mathrm{w} \%$ of secondary raw materials to the industry sector (Linzner and Salhofer, 2014). Wilson et al. (2012) pointed out that some developing countries have material recovery rates comparable to developed countries due to the existence of an informal waste management sector. In these countries, the performance of the informal sector in the recycling chain still brings 
considerable savings to official urban cleaning services.

In developing countries, recycling solid waste is more likely to be achieved through waste pickers in an informal market than by formal stakeholders in the supply chain (Gutberlet et al., 2017; Ferronato et al., 2019). Aparcana and Salhofer (2013) defined the informal market as individuals or groups who carry out various activities within SWM. The public authority or society in general does not officially recognize the role of these individuals and groups. As in any market, some labor relationships are established in the informal market, which has main stakeholders: waste pickers, waste traders/middleman, and the recycling industry. In some cities in Thailand and China, some waste collectors work motorized, collect by going door to door, and are already vital to local SWM (Wilson et al., 2006). In Beijing (China), they are known as waste merchants and have higher productivity than traditional waste pickers (Steuer et al., 2017).

The informal waste recycling market is often the main source of income and survival for poor and marginalized people (Sembiring and Nitivattananon, 2010). Basically, there are two types of waste pickers: street pickers (or ambulatory waste pickers), who roam about the city searching for materials considered to have some economic value, and dumpsite pickers, who live and/or work on dumpsites (Rathana, 2009). Typically, waste pickers have a low level of formal education (Rankokwane and Gwebu, 2006; Rockson et al., 2013; Martins et al., 2014). However, they have good enough knowledge and the skills necessary to segregate the type of waste desired by the market (Oguntoyinbo, 2012).

Generally, waste picking is low-income labor, and many waste pickers work for survival (Wilson et al., 2006). Some authors reported the income of waste pickers as follows: in Nigeria, waste pickers earn about 50 US dollars per month (Nzeadibe, 2009); in Bangladesh, they earn from 0.85 to 1.89 euros per day (Bari et al., 2012); in Ghana, they earn from 7 to 17 US dollars per day (Rockson et al., 2013); in Beijing (China), from 2013 to 2016, waste pickers earned 650 renminbi, waste merchants earned 3000 renminbi, and middlemen earned 2000 renminbi, with declining incomes (Steuer et al., 2018); and in Côte D'Ivoire, they earn about 115 US dollars per month (Andrianisa et al., 2016). In Bantar Gebang (Indonesia), the average household income is approximately 216 US dollars per month (Sasaki et al., 2014).

Informal work forms the basis of the recycling market in Brazil (Campos, 2014; Ferri et al., 2015; Tirado-Soto and Zamberlan, 2013). These waste pickers carry out their work on the streets and in dumpsites. In addition to the unhygienic conditions of this type of work, Fergutz et al. (2014) pointed out that Brazilian waste pickers receive inadequate remuneration from the buyers of recyclable material (waste traders/middlemen and the recycling industry), who pay too little or pay with food or alcohol instead of cash.

Despite waste picking being a source of income for several families in poverty, according to Wilson et al. (2006), it uses the labor of those considered socially vulnerable, such as women, children, and older adults, and exposes them to health risks. Waste pickers are involved in various types of waste-handling activities, which results in serious concern due to associated occupational health risks and hazards (Gutberlet and Uddin, 2017; Ravindra, 2016). Due to their work in landfills and dumpsites, these workers are characterized by extremely poor conditions, which include a propensity for diseases, poor labor conditions, limited access to facilities and infrastructure, no provision of water supply and sanitation, an absence of social safety networks, and shorter life expectancy (Afon, 2012; Gonzenbach and Coad 2007; Wilson et al., 2006; Agarwal et al., 2005). In addition, waste pickers are usually exposed to the stench of waste and vast amounts of pests and dangerous materials, such as medical and other biohazardous waste (Negreiros et al., 2019; Sasaki et al., 2014), waterborne (Cruvinel et al., 2019) and vectorborne diseases (Cruvinel et al., 2020). An incident with international repercussions occurred at the Aguazinha dumpsite in 1994 when a family was found handling anatomical parts from hospital waste (Garcia and Zanetti-Ramos, 2004).

\section{Integration of the informal recycling sector into municipal waste management}

Actions to improve the municipal SWM, such as closing dumpsites, adopting selective collection, and using mechanized equipment for sorting waste, may lead to waste picker unemployment (Marello and Helwege, 2014; Sembiring and Nitivattananon, 2010). Hartmann (2018) showed how the modernization of SWM and the transformation of a waste dumpsite into a sanitary landfill in Managua (Nicaragua) affected the subsistence of waste pickers, particularly by reducing job opportunities. The author concluded that the social and economic impacts of this change on the lives of the waste pickers should be critically analyzed, regardless of other benefits. 
In developing countries, waste pickers play an important role and contribute greatly to SWM by reducing government costs through collection and treatment. Considering the work experience of waste pickers in recyclable materials, it should be easy to integrate them into any municipal SWM system. Nevertheless, the formalization of waste picking in SWM is an important challenge that municipal managers must accept. Many barriers impede the integration of waste picking in SWM, and the negative perception on waste pickers by society/government is constantly referred to in the literature (see Aparcana, 2017; Fergutz et al., 2014; Oguntoyinbo, 2012; Paul et al., 2012; Sembiring and Nitivattananon, 2010). Based on a case study in the Suzhou urban area, China, Fei et al. (2016) pointed out that the government could provide professional training, tax deductions, information platforms, and recycling equipment to the informal sector, as well as promote a resource management system with complete extended producer responsibility, to integrate these stakeholders into SWM. On the other hand, many waste pickers are reluctant to integrate into the formal market for fear of losing their autonomy and/or earning reduced profits (Alparcana, 2017; Colombijn and Morbidini, 2017; Fergutz et al., 2014).

According to Alparcana (2017), the three most common forms of formalization of waste pickers in the labor market are (i) those based on organizing informal waste workers in associations and cooperatives (examples in the Philippines, Brazil, Colombia, Peru, and India); (ii) those based on organizing recyclers in community-based organizations or micro- and small enterprises (examples in Kenya, Zambia, Tanzania, Uganda, Egypt, and Honduras); and (iii) those based on adopting informal waste workers as workers for the formal SWM sector (examples in Indonesia, India, Bangladesh, and Peru). Informal integration between the government of Abidjan (Côte d'Ivoire) and waste pre-collectors (a group formed by private individual household waste pre-collectors composed mostly of young, unemployed people) is described in Andrianisa et al. (2016) as being insufficient to ensure quality of life to the workers, despite the benefits widely recognized by the population. Paul et al. (2012) described the positive integration of the informal waste sector in SWM, which involved 240 waste pickers in Iloilo city (Philippines) and contributed toward poverty alleviation, increasing participant's incomes and improving their working conditions. Diaz and Otoma (2012) presented a case study in Chiclayo (Peru) in which waste picking resulted in a reduction of collection routes; however, the synergy between municipal systems and informal recycling can be maximized if new operational conditions, such as campaigns to raise residents' awareness of waste reduction, prevention, and recycling, are implemented. In Sorocaba city (Brazil), Lima and Mancini (2017) estimated that the cooperatives and autonomous waste pickers achieve recovery rates of $9 \%$. In general, the Brazilian government estimates that the informal recovery rate of waste materials is approximately 1\% (SNIS, 2014). Gall et al. (2020) presented a case study about an integration between industry and informal recycling market in Nairobi (Kenya) that is comparable to the sophisticated formal recycling system of high-income countries. The material (waste) was pre-sorted by an individual waste picker and subsequent industrial scale sorting and washing resulted in a recyclable material with good composition and properties.

In general, most authors agree that the informal waste market should be integrated into formal SWM to create new jobs, to recover material, and to avoid pollution in developing countries. The key issue is defining the ideal way to integrate the formal and informal sectors. This method covers understanding the waste pickers' needs, creating partnerships among all stakeholders involved in SWM (Sembiring and Nitivattananon, 2010), and utilizing - with little alteration - the existing framework of informal recycling market (Sasaki et al., 2018). All these interventions would generate new costs that could be covered by the redistribution of resources already available to the SWM. For example, according to NPSW, only refuse should be destined for landfills, but municipalities allocate all collected waste to landfills. If the law were enforced and only the refuse was sent to landfills, there would be a surplus in the budget that could be used to fund the selective collection and separation of recyclables.

From an environmental point of view, the closure of dumpsites did not mean a major change in the SWM standard. Unlike the closed dumpsites, the landfills have pollution-control infrastructure. Nevertheless, all waste is still sent to such landfills without the recovery of energy or new materials. However, the closure of dumpsites in waste picking means a major change and has received little attention in the specialized literature, despite the relevance of the issue. In this context, this research contributes to addressing the theme by considering the functioning of the informal recycling market, its main stakeholders (with a focus on waste pickers), its opportunities for integration into the official SWM, and its main fragilities.

\section{Materials and Methods}


Revista Brasileira de Geografia Física, Vol. 13, n. 05 (2020) 1953-1969.

To illustrate the current waste picking conditions in Recife, Olinda, and Jaboatão dos Guararapes, after the closure of the dumpsitesfrom a socioeconomic perspective and accepting that there was a transformation in the waste pickers' life conditions - a methodology based on direct interviews with a pre-structured questionnaire was proposed. The questionnaire was created to obtain the best representation of the reality of the informal recycling market (waste pickers, cooperatives, waste traders, and the recycling industry) and to understand the changes and impacts caused by the closure of two large dumpsites. The first methodological step consisted of surveying the main waste picker cooperatives, associations, and/or similar organizations in the three municipalities of interest. This survey was based on the information provided by the governments of Recife, Jaboatão dos Guararapes, and Olinda.

From this survey, the cooperatives were contacted, and 39 collectors were selected and distributed in the three municipalities, according to Figure 1. From the 20 organized groups of collectors, 11 were selected for visitation and interviews. From these initial surveys, waste traders/middlemen and industries that configure the intermediate and final link of the recycling chain in RMR were also identified, visited, and interviewed.

Finally, the empirical study was conducted with 39 waste pickers, 11 waste picker cooperatives, 8 waste traders, and 5 representatives from the recycling industry. Via a questionnaire, the waste pickers answered several questions, including those about their monthly income, age, gender, educational level, time in their profession, whether they were linked to cooperatives, whether they were enrolled in social programs, whether they worked in dumpsites, and if the informal recycling market changed with the closure of the dumpsites. The survey was conducted between January and June 2015.

Shaping the sample for the survey was difficult because waste pickers, especially those belonging to cooperatives, refused to do interviews. The represented sample was determined from the statistical equation for finite samples (Eq.1):

$$
n=\frac{N * Z^{2} * P *(1-P)}{(N-1) * e^{2}+Z^{2} * P *(1-P)^{\prime}} \quad \text { Eq. } 1
$$

where $\mathrm{n}$ is the sample size ( 39 waste pickers); $\mathrm{N}$ is the size of the universe (a value of 1300 [Melo, 2001; Vector, 2005; AMS/SA Paulista, 2005] that was adopted, which corresponds to an estimate of the number of collectors who have been demobilized); $\mathrm{P}$ is the expected proportion of the sample (only $5 \%$ of respondents were considered not to provide representative information for the research object); e is the maximum allowable margin of error; and $\mathrm{Z}$ is the confidence level of the results.

Considering $\mathrm{Eq} 1$ and aiming to find parameters e and $\mathrm{Z}$, we reach values of $6.8 \%$ for the maximum allowed error and $95 \%$ for the level of confidence of the obtained results. These values are compatible with the type of research and the type of results sought, which aim to provide an overview of the situation, without any deep knowledge about any of the strands surveyed.

A qualitative and quantitative analysis of the collected data was adopted. This approach was necessary to establish relationships between the variables from the content analysis obtained through the questionnaire. Minitab® 17.1.0 (2013), a type of statistical software, was used to analyze data, and Spearman correlation and chi-square tests were conducted. Correlation is any statistical association that refers to how close two variables are to having a linear relationship with each other. For the purpose of this paper, a correlation analysis may be useful because it can indicate a predictive relationship that can be exploited in practice. Hence, in this study, six Spearman correlation tests were performed regarding four ordinal variables, and three chi-square tests were performed to test the relationship among three qualitative variables. Of all the statistics based on ranks, Spearman's coefficient of correlation for ranks appeared first and it is perhaps the best known. This statistic is an association measure that demands that both variables are at least on an ordinal scale (Siegel and Castelan Jr., 1988). The Pearson chi-square test is performed to verify if there is an association between two qualitative variables.

From the results of the structured interviews and correlations obtained, it was possible to illustrate a brief profile of the waste pickers who worked in the region of the two closed dumpsites. The other stakeholders were approached and asked for information on the informal recycling market through semi-structured interviews.

\section{Results and Discussion}

The data collected through the questionnaires and interviews helped researchers understand the current situation of the recycling chain in the municipalities of Recife, Olinda, and Jaboatão dos Guararapes and helped them compare it with the situation prior to the closure of the 
dumpsites. The survey helped create a profile of the waste collectors to understand the functioning of the informal recycling market established in the vicinity of the closed dumpsites, as shown in the following sections.

\section{Profile of the waste pickers}

From the 39 waste pickers interviewed, 19 worked in the closed dumpsites, and 20 were street pickers. Only nine waste pickers were linked to cooperatives, the others worked individually and independently. Waste pickers from cooperatives were less receptive to interviews. Most street waste pickers showed an aversion to collective work such as in cooperatives. Figure 2 summarizes the profile of the waste pickers interviewed.

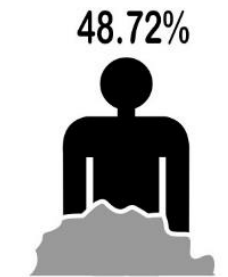

Former dumpsite waste pickers

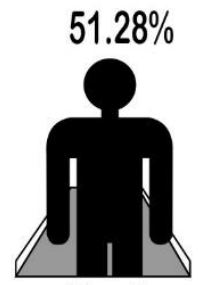

Street waste pickers
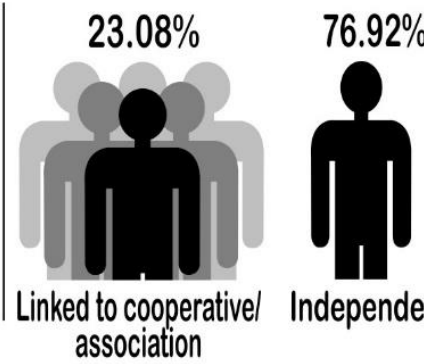

Independent association

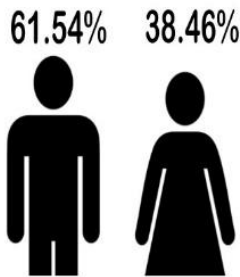

Male

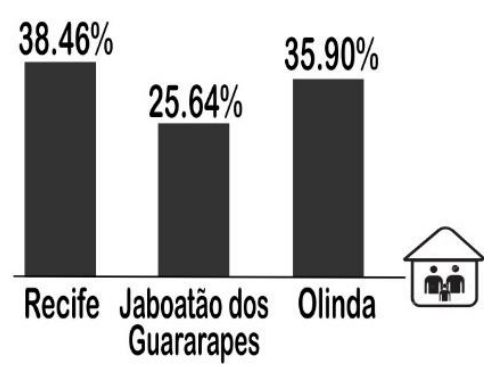

\section{Participation in cooperatives and associations}

Approximately $23 \%$ of waste pickers are linked to cooperatives. The data from the nine cooperatives surveyed reveal that the total number of cooperative members (142 people) represents less than $11 \%$ of the approximately 1300 waste pickers who worked at the Aguazinha and Muribeca dumpsites. In this regard, there is no significant change in the waste-picking activity, because the waste pickers did not generally adhere to the cooperatives, even when the two dumpsites were operating. Considering that nine of the 11 cooperatives reported having support from the government, these incentives do not appear to be enough to persuade the waste pickers to accept the cooperative model. The reasons for a lack of acceptance are diverse and range from the rigidity of schedules and procedure to misunderstandings related to the effort/remuneration relationship among the members. The compensation framework is also one of the main obstacles. Individual informal waste picking results in daily remuneration; the process is collection, selling (to a waste trader), and receiving remuneration. In a cooperative model, remuneration is by equitable sharing of profits and is made on a fortnightly or monthly basis. Another reason is that in cooperatives, when some recyclable material loses its value in the market and accumulates in plants, the waste pickers are unable to bring new materials to these places, which also decreases their incomes. In this context, waste traders/middlemen who have infrastructure, logistics, and working capital can store waste longer, buy products at lower prices, and sell when prices are higher in the market. All of these factors make waste pickers sell recyclables to middlemen, making the cooperative model unattractive to them. The leaders of the cooperatives interviewed suggested that public authorities institute a policy of regulation for the prices of recyclables to protect the work of cooperatives from these market oscillations, which could result in a more effective participation by waste pickers. Yu et al. (2020) argue that formalizing waste picking activities through the formation of cooperatives can be counterproductive because it internalizes some of the positive externalities offered to municipalities and the recycling industry.

The immediacy of obtaining money from recycling and the availability of material in the dumpsites explained the presence of huge contingents of people in the Muribeca and Aguazinha dumpsites. Many of those people were not waste pickers, but chemical dependents or alcoholics who found a simple framework with which to sustain their dependence. Slivnik et al. (2012) showed that one of the waste picker profiles includes homeless people in situations of social exclusion, including those who are drug addicts, alcoholics, and people with mental health problems. Nowadays, individuals or waste pickers linked to a cooperative have to be more professional to obtain results, which indicates that, with the closure of the dumpsites, there was a greater selectivity in the people who wanted to work.

From a legal point of view, the NPSW provides the instruments and guidelines needed to support and integrate the waste pickers into the official SWM (Oliveira et al., 2017). The NPSW encourages the creation of cooperatives and associations as a method of social inclusion and the economic emancipation of waste pickers in Brazil 
Revista Brasileira de Geografia Física, Vol. 13, n. 05 (2020) 1953-1969.

in conjunction with selective collection programs, reverse logistics, the elaboration of municipal plans for integrated waste management, the closure of dumpsites, and so on. However, after nine years, the real gains from the NPSW are incipient. What was considered to be a priority within the NPSWthe definitive closure of the dumpsites until 2014 and only sending waste to the sanitary landfillsare still far from being achieved. As in a cascade effect, other actions, such as support for waste pickers, lost their incentive and priority as future topics.

The issue of gender in waste picking

Regarding gender, the waste pickers interviewed were mostly men (61.54\%). Yu et al. (2020), Rockson et al. (2013), Oguntoyinbo (2012), Afon (2012), and Rankokwane and Gwebu (2006) reported a similar predominance of male waste pickers. Male waste pickers travel several kilometers a day with garbage carts. Female waste pickers prefer to have fixed collection points (in commercial areas) or to accompany their husbands during their waste-picking activities. Although Andrianisa et al. (2016) pointed out that scavenging is highly energy dependent and that this is the reason that more men are involved in it than women, this is not fully valid regarding the working conditions in the nine cooperatives visited, where more women were found working than men. A study performed in Santo André (Brazil) by Gutberlet and Baeder (2008) concluded that a proper sorting infrastructure for separation of waste is important should take into consideration specific gender-related needs; for instance, mostly women are involved in the separation.

About $23 \%$ of waste pickers were linked to cooperatives, and the majority were women. Despite the link to cooperatives allowing them to achieve better working conditions (Medina, 2000), some waste pickers prefer the freedom of working individually under liberal market conditions (Colombijn and Morbidini, 2017).

Table 1 shows a summary of the waste pickers' profiles according to gender. In the 11 cooperatives, 142 people worked in total, of which $60.6 \%$ were women and $39.4 \%$ were men. In this case, the profile of the waste picker, in terms of gender, cannot be said to have changed as a result of the closure of the dumpsites. However, as noted by Gutberlet and Baeder (2008), women are more likely to separate recyclables than to be involved in waste collection.

Although the waste pickers are from an extremely vulnerable social strata, only $38.5 \%$ of respondents (15 waste pickers) claimed to receive some type of financial aid, of which $86.7 \%$ were women who received the Bolsa Família (in
English, Family Grant). The correlation between gender and social programs (specifically the Bolsa Família program) is shown in Table 2; this table shows the results of three chi-square tests (with $\alpha=$ $0.05)$ regarding gender, whether the waste pickers worked in dumpsites, and whether the waste pickers were enrolled in social programs. The Bolsa Família program is a direct income transfer program that is aimed at families living in poverty and extreme poverty in Brazil. According to Nascimento (2016), women are the primary recipients of the Bolsa Família program because they are most often responsible for the family.

Income from waste picking

Information related to the waste pickers' incomes is not easy to obtain (Steuer et al., 2017). Part of this difficulty lies in the fact that it is possible to determine the gains from waste picking with some precision, but not the working hours associated with this income.

In this case, most of the waste pickers (84.62\%) reported a monthly income ranging from 150 to 300 US dollars. A similar result was found by Martins et al. (2014) regarding waste pickers in central Brazil. These revenue values are higher than those found in Abidjan, Côte D'Ivoire (Andrianisa et al., 2016), Enugu, Nigeria (Nzeadibe, 2009), and Bangladesh (Uddin et al., 2020; Bari et al., 2012). Yu et al. (2020) found an average income of 2900 rand (approximately 170 US dollars) for waste pickers in Bellville (South Africa).

The average value of 150 to 300 US dollars is equivalent to approximately half of the minimum wage and minimum wage in full in Brazil in 2018, which is exactly the same income that the waste pickers earned. They currently maintain wastepicking activities at the same level as those conducted when the Aguzinha and Muribeca dumpsites were in operation; at that time, the per capita gain was similar to minimum wage (IPEA, 2012; AMS/SA Paulista, 2008; Vector, 2004).

This result can be further reinforced by the interviewees' perception of income after the dumpsites were closed. In fact, a larger contingent of waste pickers, cooperatives, and waste traders reported that there was no change in income after the dumpsites closed (Figure 3).

The cooperatives showed the greatest changes related to the modification in income, with $36.36 \%$ reporting that gains increased after the closure of the dumpsites. On the other hand, $18.18 \%$ of the cooperatives reported income reduction, as they also had the highest percentage regarding this question. 
Table 1. Summary of waste pickers' profiles according to gender

\begin{tabular}{|c|c|c|c|c|c|c|c|c|c|c|c|c|c|c|c|c|c|}
\hline \multirow[b]{2}{*}{ Gender } & \multirow[b]{2}{*}{$\%$} & \multicolumn{3}{|c|}{ Income (US dollars) } & \multicolumn{3}{|c|}{ Age group (years) } & \multicolumn{2}{|c|}{$\begin{array}{c}\text { Time in profession } \\
\text { (years) }\end{array}$} & \multicolumn{3}{|c|}{ Linked to cooperative } & \multicolumn{3}{|c|}{ Education level } & \multicolumn{2}{|c|}{$\begin{array}{c}\text { Receives government } \\
\text { support }\end{array}$} \\
\hline & & $<150$ & $150-300$ & $>300$ & $1 / / 8-30$ & $31-45$ & $>45$ & $01-05$ & $>05$ & Yes & No & Unschooled & $\begin{array}{l}\text { Elementary } \\
\text { school } \\
\text { (unfinished) }\end{array}$ & $\begin{array}{l}\text { Elementary } \\
\text { school }\end{array}$ & $\begin{array}{l}\text { High school } \\
\text { (unfinished) }\end{array}$ & Yes & No \\
\hline Male & $\begin{array}{c}24 \\
(62.0 \%)\end{array}$ & $\begin{array}{c}0 \\
(0.0 \%)\end{array}$ & $\begin{array}{c}21 \\
(87.5 \%)\end{array}$ & $\begin{array}{c}3 \\
(12.5 \%)\end{array}$ & $\begin{array}{c}3 \\
(12.5 \%)\end{array}$ & $\begin{array}{c}13 \\
(54.2 \%)\end{array}$ & $\begin{array}{c}8 \\
(33.3 \%)\end{array}$ & $\begin{array}{c}3 \\
(12.5 \%)\end{array}$ & $\begin{array}{c}21 \\
(87.5 \%)\end{array}$ & $\begin{array}{c}4 \\
(16.7 \%)\end{array}$ & $\begin{array}{c}20 \\
(83.3 \%)\end{array}$ & $\begin{array}{c}6 \\
(25.0 \%)\end{array}$ & $\begin{array}{c}15 \\
(62.5 \%)\end{array}$ & $\begin{array}{c}3 \\
(12.5 \%)\end{array}$ & $\begin{array}{c}0 \\
(0.0 \%)\end{array}$ & $\begin{array}{c}2 \\
(8.3 \%)\end{array}$ & $\begin{array}{c}22 \\
(91.7 \%)\end{array}$ \\
\hline Female & $\begin{array}{c}15 \\
(38.0 \%) \\
\end{array}$ & $\begin{array}{c}3 \\
(20.0 \%)\end{array}$ & $\begin{array}{c}12 \\
(80 \%)\end{array}$ & $\begin{array}{c}0 \\
(0.0 \%) \\
\end{array}$ & $\begin{array}{c}4 \\
(26.7 \%) \\
\end{array}$ & $\begin{array}{c}6 \\
(40.0 \%) \\
\end{array}$ & $\begin{array}{c}5 \\
(33.3 \%)\end{array}$ & $\begin{array}{c}5 \\
(33.3 \%) \\
\end{array}$ & $\begin{array}{c}10 \\
(66.7 \%) \\
\end{array}$ & $\begin{array}{c}5 \\
(33.3 \%) \\
\end{array}$ & $\begin{array}{c}10 \\
(66.7 \%) \\
\end{array}$ & $\begin{array}{c}4 \\
(26.7) \\
\end{array}$ & $\begin{array}{c}8 \\
(53.3 \%) \\
\end{array}$ & $\begin{array}{c}2 \\
(13.3 \%)\end{array}$ & $\begin{array}{c}1 \\
(6.7 \%) \\
\end{array}$ & $\begin{array}{c}13 \\
(86.7 \%) \\
\end{array}$ & $\begin{array}{c}2 \\
(13.3 \%) \\
\end{array}$ \\
\hline
\end{tabular}

Table 2. Pearson chi-square tests

\begin{tabular}{lccc} 
& \multicolumn{1}{c}{$\begin{array}{l}\text { Pearson chi- } \\
\text { square }\end{array}$} & $\boldsymbol{p}$ value & Correlation \\
\hline Gender x worked in dumpsite & 0.208 & 0.648 & No \\
\hline $\begin{array}{l}\text { Gender x social program (Bolsa } \\
\text { Família) }\end{array}$ & 23.931 & 0.000 & Yes \\
\hline $\begin{array}{l}\text { Worked in dumpsite x social program } \\
\text { (Bolsa Família) }\end{array}$ & 1.242 & 0.264 & No \\
\hline
\end{tabular}


In any case, there was no outstanding difference in the incomes of the waste pickers who marketed with waste traders/middlemen and the cooperative who traded directly with the industries. Perhaps this is another key aspect that can explain the low motivation of the waste pickers regarding the cooperative model. Many waste pickers claim that the freedom to establish their own work regimen and to market when and with whom they want is important, which is not possible in the cooperative regimen.

Regarding income, there was no clear correlation between the time in the profession and the gains made. This is an important aspect to be analyzed, because on one hand, experience is gained over the years, but on the other hand, the physical force required to carry out waste picking in the current models is lost. Although there is no such correlation, it is known that the more experienced the waste pickers are, the more they know about the recyclable market. This knowledge can increase their bargaining power compared to those who have less experience in the profession. Most of the sample is made up of people over 30 years old $(82.05 \%)$ who, for the most part, have been working in this industry for more than 5 years (Figure 4). It is important to emphasize that $48 \%$ of the sample corresponds to the former waste pickers of the Muribeca and Aguazinha dumpsites (Figure 2 ), which means that they are people with more than 8 years of experience. Most waste pickers (male, $87.5 \%$, and female, $66.7 \%$ ) have been active for more than five years (Table 1). None of them have been involved in the activity for less than a year.

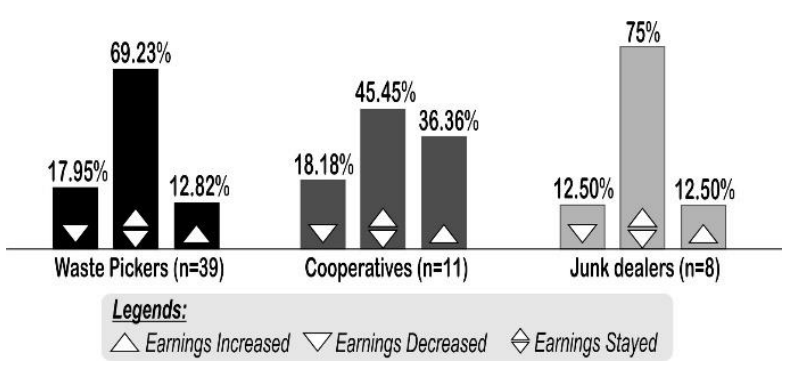

Figure 3. Perception of the recycling market in relation to the behavior of income after the dumpsites closed

Relationship between waste picking and other variables

Table 3 presents the results of six Spearman correlation tests regarding age, time in the profession, income in the profession, and education level. There are no correlations among these variables (with $\alpha=0.05$ ). One reason is that unlike other activities, there are no restrictions on age, schooling, or working experience for waste picking. This is why the activity is rather dynamic, and any individual who does not have specific skills can find a livelihood in waste picking, even temporarily. Regarding income, unlike other professions, the lack of relationship between experience with the activity and income shows that the experience in waste picking is acquired over time; it allows the specialization and optimization of effort but does not necessarily increase income.

Table 3. Spearman correlation tests

\begin{tabular}{cccc} 
& $\begin{array}{c}\text { Spearman } \\
\text { coefficient }\end{array}$ & $\boldsymbol{p}$ value & Correlation? \\
\hline Age x time in profession & 0.191 & 0.245 & No \\
\hline Age x income in profession & 0.082 & 0.618 & No \\
\hline Age x education level & -0.298 & 0.065 & No \\
\hline $\begin{array}{c}\text { Time in profession x income in } \\
\text { profession }\end{array}$ & 0.162 & 0.325 & No \\
\hline $\begin{array}{c}\text { Time in profession x education level } \\
\text { Income in profession x education } \\
\text { level }\end{array}$ & -0.086 & 0.601 & No \\
\hline
\end{tabular}

Regarding education, the results show that about $26 \%$ of respondents claimed to be illiterate, when the average rate of illiteracy in Brazil is approximately $7 \%$, according to the Brazilian Institute of Geography and Statistics (IBGE, 2018). On the other hand, the report by the IPEA (IPEA, 2012) indicated an illiteracy rate of $34 \%$ for the northeast waste pickers, which is even higher than shown in this study. According to Figure 4, 58.97\% of respondents stated that they had unfinished elementary education and only $2.56 \%$ of those interviewed went to high school, although they did not complete their education there. The results confirm that waste picking continues to be carried out by marginalized people, just as it did when the dumpsites were operational. 


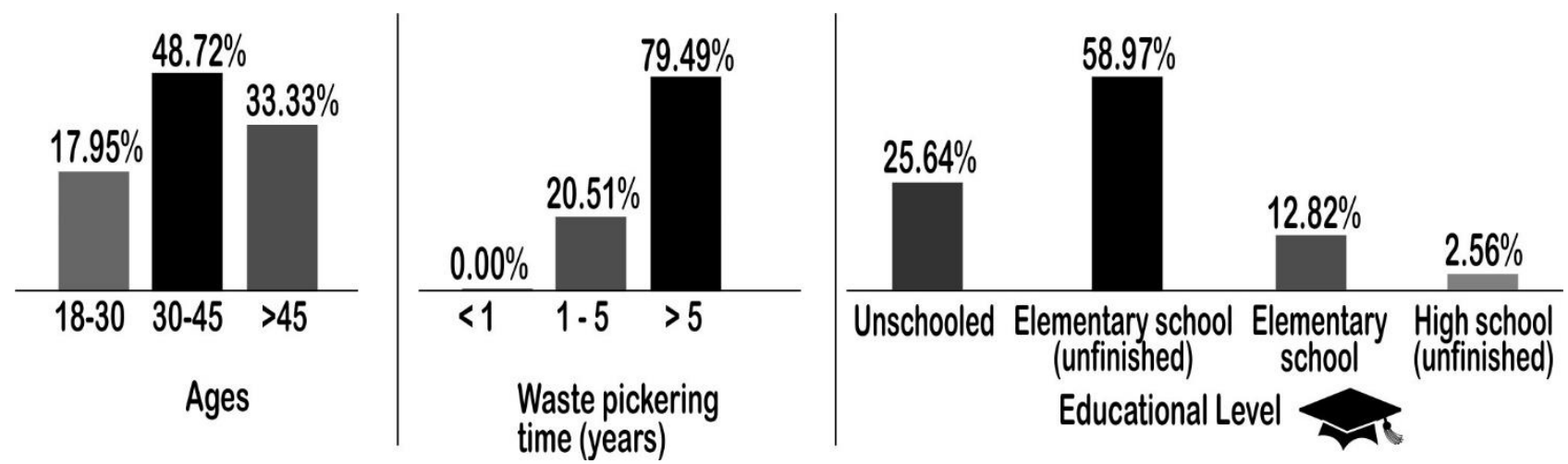

Figure 4. Profile of the waste pickers interviewed

From the seven waste pickers interviewed who are 30 years old or younger, only one was reported to be illiterate. The group of people between 18 and 30 years old represented the lowest percentage of the sample, with a participation of $17.95 \%$. Although not conclusive, these data may indicate that the socioeconomic improvements in Brazil and RMR in the last decade also reflect in the collectors' profiles, reducing the percentage of young, excluded people who find waste picking to be a livelihood alternative.

Despite the higher education levels among female waste pickers, incomes are higher among male waste pickers (Table 1). Reasons, such as physical limitations and greater domestic responsibility, might justify these differences.

From the integrated analysis of education data and the perception gained after the cooperative visitation and interviews with the waste pickers, it was noticed that the educational level is far below that needed to succeed in an activity that demands entrepreneurship from waste pickers. This fact hinders the implementation of empowerment and professional actions and access to government incentives created for this purpose.

From the 11 cooperatives surveyed in the three municipalities, 7 (63.64\%) reported that their waste pickers had some type of professional training, and $9(81.82 \%)$ reported that they are supported in some way by the government. The type of professional training or support received was not in the scope of this research. However, it was possible to verify that none of these cooperatives works in a professional mannerwith time control, use of personal protective equipment, use of management indicators, compliance with labor safety norms, among other aspects - which indicates the capacity for growth and a self-sustaining operating condition. On the contrary, what is observed is that the cooperatives continue to be highly vulnerable and dependent on the government's actions.
Another negative point observed in cooperatives concerns organizational leadership. Leadership in cooperatives/associations is naturally performed by former waste pickers who were already leaders in the dumpsites. However, these leaders are not always the most suitable to lead a group in a cooperative work model, causing some concurrence and discouraging the adherence of new members.

The work done in cooperatives, under appropriate conditions, would be the best form of empowerment for the waste pickers in the informal recycling market. However, due to some factors, such as those reported above, the model of working in cooperatives is unattractive and, in some cases, unhelpful for waste pickers. Therefore, and due to the lack of linked waste pickers, cooperatives have their importance, penetration, and power diminished in the informal recycling market.

\section{Trade of Recyclable Material}

Part of the research was strategically aimed at understanding the current commercial relationships among the various stakeholders in the recycling chain and assessing whether there was a relevant change in this issue because of the closure of the dumpsites.

The 30 street pickers interviewed reported that they preferred to sell recyclables to waste traders rather than to the cooperatives. From these 30 street pickers, only one also sells to cooperatives. The preference is based on the price paid for the products, which is higher when sold to waste traders. Independent waste pickers cannot sell to recyclers like waste traders and cooperatives do.

According to some cooperative waste pickers, waste picking was easier in the dumpsite because the amount of waste was plentiful and the waste traders were nearby and familiar with their surroundings. On the other hand, work linked to cooperatives allows a better quality of life, since the health conditions are improved. Many waste 
traders had to change their deposit sites, usually rather close to the dumpsites, due to the closure of these sites.

The visited cooperatives were located in Recife (3 cooperatives), Jaboatão dos Guararapes ( 3 cooperatives), and Olinda ( 2 cooperatives). Of the eight cooperatives, four were less than five years old (formed between 2010 and 2015), and were possibly formed to assist waste pickers displaced by the two-dumpsite closure. More than half of the cooperatives receive some kind of support from municipal governments (operational and logistical support or vocational training). Two cooperatives were independent of governmental support and had partnerships with an international institute of technology and with a significant recycling enterprise.

In the survey conducted directly with the cooperatives' presidents, $58 \%$ of the 11 presidents reported that they negotiate products with the intermediation of waste traders, while $42 \%$ said that they sell directly to the recycling industry.

The results show that $69 \%$ of the waste pickers, $67 \%$ of the middlemen, and $62 \%$ of the cooperatives reported that income remained the same after the closure of the dumpsites. The others were divided between those who thought rent had gone up and others who thought rent had fallen. More than half of the stakeholders interviewed reported that income remained the same or even increased after the closure of the dumpsites. Government support for the formation of cooperatives and the adaptation of dumpsite waste pickers to street work may have mitigated the impact of the closure of the dumpsites on the informal market.

Plastic, paper/cardboard, and metal are the most marketed materials, with the following prices (US dollar/kg), respectively: 0.21-0.47, 0.03-0.10, and 1.07 (aluminum can) and 3.9-4.69 (copper). The cooperatives and middlemen only carry out the storage, segregation, and pressing of the waste; they avoid cleaning operations due to the wastewater treatment costs. The survey showed that all the interviewed industries work with more than $50 \%$ of the raw material formed by recyclable materials bought from legalized companies (cooperatives or middlemen), since they are subject to periodic internal audits. Only $54.5 \%$ of the cooperatives and $12.5 \%$ of the middlemen interviewed work with glass collection due to the need to work with special personal protective equipment, which increases operating costs.

The paper industry was the only one to report that after the closure of the dumpsites, the supply of waste paper decreased, increasing material prices. Sometimes, cooperatives make an attempt to control the market, stocking recyclable materials and waiting for increased market prices for sale.

Finally, the responses and data obtained from the middlemen and the recycling industries visited not only corroborate the responses of the collectors and the cooperatives but show that the middleman figure, as an intermediate link in the chain, is still important within the market dynamics of informal recycling in the RMR, just as it was when the dumpsites operated.

The scope of the research does not directly determine whether the conditions for the negotiation of the recyclable materials with the deposit sites have improved in relation to the past, which would be important to improve the working conditions of the collectors. However, considering that $97.44 \%$ of the interviewees still negotiate with waste traders and that $69.23 \%$ of the waste pickers (Figure 3) stated that there was no variation in their income, it can be inferred that the current interrelationships between the cooperatives and the waste traders and between the waste pickers and the waste traders are still quite similar to those in the past, at least as far as income is concerned.

\section{Conclusion}

The closure of the Aguazinha and Muribeca dumpsites can be considered one of the main landmarks in the modern SWM in the RMR. The restriction of a large number of waste pickers working under subhuman conditions at the two dumpsites is supported by the UN's 8th Sustainable Development Goal in promoting sustained, inclusive, and sustainable economic growth; full and productive employment; and decent work for all (UN, 2018).

After these dumpsites were closed, the logistics of the waste pickers was partly broken due to the exit of the main waste traders near the dumpsites. This research helped show that 8 years after the dumpsites closed, waste picking carried out by groups of waste pickers had undergone some noticeable changes, but the activity was not substantially transformed. The aspects related to the saturation of the activity or an excessive number of people performing this type of work were not observed in any of the interviews. In this sense, it can be deduced that the difficulty of access to the material, which implies solid waste picking in the street or in a cooperative instead of directly waste picking from the dumpsites, may have reduced the total number of people involved.

The social profile, identified in the researched group, continues to be highly vulnerable individuals with low levels of formal education who find a form of subsistence in waste 
Revista Brasileira de Geografia Física, Vol. 13, n. 05 (2020) 1953-1969.

picking based on their possibilities for employment. The identified profile also shows that the creation of associations and cooperatives, although some of them fomented by public power, still faces resistance and low adherence by waste pickers, similar to their resistance in the past. Individual waste picking on the street, with the autonomy to decide on schedules, routes, and commercialization, continues to dominate the activity, much to the detriment of the cooperative model.

The data do not reveal a significant change in the income of the stakeholders as a result of the dumpsites being closed. However, $36.36 \%$ of the cooperatives said that they had increased revenues after the dumpsites were closed. The similarity in the gains before and after the closure of the dumpsites was rather marked in the case of the deposit sites, because $87 \%$ of the interviewees reported that they did not change or that their income increased. This aspect is quite relevant because it denotes the importance of this link in the recycling chain in RMR and the need for its insertion in a fair way in any model of SWM that may be instituted.

Although the dumpsites' closure has improved the working condition of the waste pickers, the activity is still carried out in a precarious way, which is far from any type of professional standard. Waste pickers still work precariously and without official ties to the recycling industry, which is the main beneficiary of their work.

The social and environmental importance of the informal recycling market and the interest of those involved in continuing the activity and growing within it must be recognized. In this sense, a greater investment from the public in these groups, integrated with the other stakeholders, would be a method of reaching the long-soughtafter goal of making waste picking a decent, inclusive, and sustainable job.

\section{Acknowledgements}

The authors would like to thank the cooperatives and the government of Recife, Olinda and Jaboatão dos Guararapes for the interviews. This research did not receive any specific grant from funding agencies in the public, commercial, or not-for-profit sectors.

\section{References}

Adama, O., 2012. Urban Livelihoods and Social Networks: Emerging Relations in Informal Recycling in Kaduna, Nigeria. Urban Forum
23: 449-466. https://doi.org/10.1007/s12132012-9159-8

Andrianisa, H.A., Brou, Y.O.K., Séhi bi, A., 2016. Role and importance of informal collectors in the municipal waste pre-collection system in Abidjan, Côte d'Ivoire. Habitat International 53,

265-273.

https://doi.org/10.1016/j.habitatint.2015.11.036

Afon, A., 2012. A survey of operational characteristics, socioeconomic and health effects of scavenging activity in Lagos, Nigeria. Waste Management \& Research 30 (7), 664671.

https://doi.org/10.1177/0734242X12444894

Afon, A., 2007. Informal sector initiative in the primary sub-system of urban solid waste management in Lagos, Nigeria. Habitat International, 31 193-204. https://doi.org/10.1016/j.habitatint.2007.02.007

Agarwal, A., Singhmar, A., Kulshrestha, M., Mittal, A.K., 2005. Municipal solid waste recycling and associated markets in Delhi, India. Resources Conservation and Recycling, 44 (1), 73-90. https://doi.org/10.1016/j.resconrec.2004.09.00 7

AMS/SA Paulista, 2005. Estudo de Impacto Ambiental do Aterro Sanitário Domiciliar Lote 5 - Usina Muribequinha [Environmental Impact Assessment of Sanitary Landfill Allotment 5 Usina Muribequinha]. Recife. (in Portuguese)

Aparcana, S., 2017. Approaches to formalization of the informal waste sector into municipal solid waste management systems in low- and middleincome countries: Review of barriers and success factors. Waste Management, 61, 593607.

https://doi.org/10.1016/j.wasman.2016.12.028

Aparcana, S., Salhofer, S., 2013. Development of a social impact assessment methodology for recycling systems in low income countries. Int. Journal of Life Cycle Assessment 18 (5), 11061115. https://doi.org/10.1007/s11367-0130546-8

Asim, M., Batool, S.A., Chaudhrya, M.N., 2012. Scavengers and their role in the recycling of waste in Southwestern Lahore. Resoures Conservation and Recycling 58, 152- 162. 
Revista Brasileira de Geografia Física, Vol. 13, n. 05 (2020) 1953-1969.

https://doi.org/10.1016/j.resconrec.2011.10.01 3

Brasil, 2010. National Solid Waste Policy [Law $12,305]$.

https://fld.com.br/catadores/pdf/politica_residu os_solidos.pdf.

Câmara Municipal do Recife: Casa de José Mariano [internet]. Recife: 2014 [accessed in 01 september 2018]. Available at: http://www.recife.pe.leg.br/noticias/excatadores-do-lixao-da-muribeca-participam-deaudiencia-publica-na-camara (in Portuguese)

Campos, H.K.T., 2014. Recycling in Brazil: Challenges and prospects. Resoures Conservation and Recycling, 85, 130-138. https://doi.org/10.1016/j.resconrec.2013.10.01 7

CEMPRE [Compromisso Empresarial Para Reciclagem], 2013. Review 2013. http://cempre.org.br/artigo-publicacao/artigos. (accessed 11 January 2018).

Colombijn, F., Morbidini, M., 2017. Pros and cons of the formation of waste-pickers' cooperatives: a comparison between Brazil and Indonesia. Decision, 44 (2), 91-101. https://doi.org/10.1007/s40622-017-0149-5

Cruvinel, V., Zolnikov, T., Bashash, M., Marques, C., Scott, J., 2019. Waterborne diseases in waste pickers of Estrutural, Brazil, the second largest open-air dumpsite in world. Waste Management, 99, 71-78. https://doi.org/10.1016/j.wasman.2019.08.035

Cruvinel, V., Zolnikov, T., Obara, M, Oliveira, V., Vianna, E., Santos, F., Oliveira, K., Scott, J., 2020. Vector-borne diseases in waste pickers in Brasilia, Brazil. Waste Management, 105, 223232.

https://doi.org/10.1016/j.wasman.2020.02.001

Diaz, R., Otoma, S., 2012. Effect of informal recycling on waste collection and transportation: the case of Chiclayo city in Peru. Journal of Material Cycles and Waste Management, 14, 341-350. https://doi.org/10.1007/s10163-012-0070-0

Fei, F., Qu, L., Wen, Z., Xue, Y., Zhang, H., 2016. How to integrate the informal recycling system into municipal solid waste management in developing countries: based on a China's case in Suzhou urban area. Resoures Conservation and Recycling, 110, 74-86. https://doi.org/10.1016/j.resconrec.2016.03.01 9

Fergutz, O., Dias, S., Mitlin, D., 2011. Developing urban waste management in Brazil with waste picker organizations. International Institute of Environemtal Development, 597, 23(2), 597608.

https://doi.org/10.1177/0956247811418742

Ferri, G.L., Chaves, G.L.D, Ribeiro, G. M., 2015. Reverse logistics network for municipal solid waste management: the inclusion of waste pickers as a Brazilian legal requirement. Waste Management, 40, 173-191. https://doi.org/10.1016/j.wasman.2015.02.036

Ferronato, N., Rada, E.C., Gorritty Portillo, M.A., Cioca, L.I., Ragazzi, M., Torretta, V., 2019. Introduction of the circular economy within developing regions: A comparative analysis of advantages and opportunities for waste valorization. Journal of Environmental Management, 230, 366-378. https://doi.org/10.1016/j.jenvman.2018.09.095

Gall, M., Wiener, M., Oliveira, C., Lang, R., Hansen, E., 2020. Building a circular plastics economy with informal waste pickers: Recyclate quality, business model, and societal impacts. Resources, Conservation \& Recycling, 156 , 104685. https://doi.org/10.1016/j.resconrec.2020.10468 5

Garcia, L.P., Zanetti-Ramos, B.G., 2004. Gerenciamento dos resíduos de serviços de saúde: uma questão de biossegurança. Cadernos de Saúde Pública 20 (3), 744-752. https://doi.org/10.1590/s0102$311 \times 2004000300011$

Gonzenbach, B., Coad, A., 2007. Solid waste management and the Millennium Development Goals. Collaborative Working Group on Solid Waste Management in Low-and Middleincome Countries, St. Gallen, Switzerland, 34p. https://s3.amazonaws.com/academia.edu.docu ments/34376747/MDG_and_SWM_Book.pdf? AWSAccessKeyId=AKIAIWOWYYGZ2Y53 UL3A\&Expires $=1542936589 \&$ Signature $=3 \mathrm{qa}$ KJnraNF5Vi6d6slqFBc5dymc\%3D\&responsecontentdisposition=inline \%3B\%20filename\%3DSolid 
Revista Brasileira de Geografia Física, Vol. 13, n. 05 (2020) 1953-1969.

_Waste_Management_and_Millennium_De.pd f

Gutberlet, J., Uddin, S.M.N., 2018. Household waste and health risks affecting waste pickers and the environment in low- and middle-income countries. International Journal of Occupational Environmental

Health. https://doi.org/10.1080/10773525.2018.148499 6

Gutberlet, J., Kain, J., Nyakinya, B., Oloko, M., Zapata, P., Campos, M., 2017. Bridging weak links of solid waste management in informal settlements. Journal of Environmental Development 26, 106-131. https://doi.org/10.1177/1070496516672263

Gutberlet, J., Baeder, A.M. (2008) Informal recycling and occupational health in Santo André, Brazil. International Journal of Environmental Health Research 18 (1); 1-15,. https://doi.org/10.1080/09603120701844258

Hartmann, C. (2018) Waste picker livelihoods and inclusive neoliberal municipal solid waste management policies: The case of the $\mathrm{La}$ Chureca garbage dump site in Managua, Nicaragua. Waste Management 71; 565-577. https://doi.org/10.1016/j.wasman.2017.10.008

IBGE, 2018. Pesquisa Nacional por Amostra de Domicílios Contínua - PNAD Contínua Educação.

https://biblioteca.ibge.gov.br/visualizacao/livro s/liv101576_informativo.pdf (accessed 20 November 2018)

IPEA, 2012. Diagnóstico sobre os catadores de resíduos sólidos. http://www.ipea.gov.br/agencia/images/stories/ PDFs/relatoriopesquisa/121009_relatorio_resid uos_solidos_urbanos.pdf

Lima, N., Mancini, S., 2017. Integration of informal recycling sector in Brazil and the case of Sorocaba City. Waste Management \& Research 35(7), 721-729. https://doi.org/10.1177/0734242X17708050

Linzner, R., Salhofer, S., 2014. Municipal solid waste recycling and the significance of informal sector in urban China. Waste Management \& Research 32(9), 896-907. https://doi.org/10.1177/0734242X14543555
Marello, M., Helwege, A., 2014. Solid Waste Management and Social Inclusion of Wastepickers: Opportunities and Challenges. Latin American Perspectives, 45(1), 108-129. https://open.bu.edu/bitstream/handle/2144/236 65/Social-Inclusion-WorkingPaper.pdf?sequence $=1$

Martins, R.M.B., Freitas, N.R., Kozlowskia, A., Reis, N.R.S., Lopes, C.L.R., Teles, S.A., Gardinalic, N.R., Pinto, N.A., 2014. Seroprevalence of hepatitis $\mathrm{E}$ antibodies in a population of recyclable waste pickers in Brazil. Journal of Clinical Virology 59, 188-191. https://doi.org/10.1016/j.jcv.2014.01.002

Medina, M., 2000. Scavenger cooperatives in Asia and Latin America. Resources, Conservation and Recycling 31, 51-69. https://doi.org/10.1016/s0921-3449(00)000719

Melo, A., 2001. Cadastro dos catadores de materiais recicláveis do aterro da Muribeca 2001 [Register of recyclable materials collectors at the Muribeca landfill-2001]. Recife: EMLURB/DLU. 11p. (In portuguese)

Nas, P.J.M., Jaffe, R., 2004. Informal waste management: shifting the focus from problem to potential. Environ. Dev. Sustain. 6, 337-353. https://doi.org/10.1023/B:ENVI.0000029912.4 1481.a5

Nascimento, A. C. de O., 2016. Mulheres e papéis de gênero no Programa Bolsa Família. http://osocialemquestao.ser.pucrio.br/media/OSQ_35_3_SL_Nascimento.pdf

Negreiros, R.V.; Araújo, F.N.F.; Silva, V.F.; Souza, P.M, 2019. Gerenciamento de resíduos sólidos de saúde em hospital universitário do Nordeste Brasileiro. Revista Brasileira de Geografia Física, 12 (1), 239-251. https://doi.org/10.26848/rbgf.v12.1.p239-251

Nzeadibe, T.C., 2009. Solid waste reforms and informal recycling in Enugu urban area, Nigeria. Habitat International 33, 93-99. https://doi.org/10.1016/j.habitatint.2008.05.006

Oguntoyinbo, O.O., 2012. Informal waste management system in Nigeria and barriers to an inclusive modern waste management system: a review. Public Health. 126 (5), 441-447. https://doi.org/10.1016/j.puhe.2012.01.030 
Revista Brasileira de Geografia Física, Vol. 13, n. 05 (2020) 1953-1969.

Oliveira, J.D., Selva, V., Pimentel, R.M.M., Santos, S.M., 2017. Resíduos eletroeletrônicos: geração, impactos ambientais e gerenciamento. Revista Brasileira de Geografia Fisíca, 10 (5) 1655-1667.

https://doi.org/10.26848/rbgf.v10.5.p16551667

Paul, J.G., Arce-Jaque, J., Ravena, N., Villamor, S.P., 2012. Integration of the informal sector into municipal solid waste management in the Philippines - What does it need? Waste Management 32 (11), 2018-2028. https://doi.org/10.1016/j.wasman.2012.05.026

Rankokwane, B., Gwebu, T.D., 2006. Characteristics, threats and opportunities of landfill scavenging: the case of GaboroneBotswana. GeoJournal. 65 (3), 151-163. https://doi.org/10.1007/s10708-005-3122-3

Rathana, K., 2009. Solid waste management in Cambodia. Cambodian Institute for Cooperation and Peace. http://cicp.org.kh/userfiles/file/Working\%20Pa per/CICP\%20Working\%20Paper\%2027\%20so lid\%20waste\%20management_Edited.pdf.

Ravindra, K., Kaur, K., Mor, S., 2016. Occupational exposure to the municipal solid waste workers in Chandigarh, India. Waste Management \& Research 34(11),1192-1195. https://doi.org/10.1177/0734242X16665913

Rockson, G.N.K., Kemausuor, F., Seassey, R., Yanful, E., 2013. Activities of scavengers and itinerant buyers in Greater Accra, Ghana. Habitat International 39, 148-155. https://doi.org/10.1016/j.habitatint.2012.11.008

Sasaki, S., Araki, T., Tambunan, A.H., Prasadjac, H., 2014. Household income, living and working conditions of dumpsite waste pickers in Bantar Gebang: Toward integrated waste management in Indonesia. Resources, Conservation and Recycling 89, 11-21. https://doi.org/10.1016/j.resconrec.2014.05.00 6

Sembiring, E., Nitivattananon, V., 2010. Sustainable solid waste management toward an inclusive society: integration of the informal sector. Resources, Conservation and Recycling 54 , 759-1026. https://doi.org/10.1016/j.resconrec.2009.12.01 0
Siegel S, Castellan Jr., N. J. Nonparametric Statistics for The Behavioral Sciences. McGraw-Hill, 1988.

Slivnik, A., Falvo, J., Sato, N., 2012. Cooperativas de manejo de resíduos sólidos urbanos: apontamentos para uma política de geração de trabalho e de renda [cooperatives for the management of urban solid waste: notes for a policy of labor and income]. ABET. XI, 98-113.

SNIS, 2014. Diagnóstico do Manejo de Resíduos Sólidos Urbanos - 2012. Brasília, Brazil: Ministério das Cidades.

Steuer, B., Ramusch, R., Salhofer, S., 2018. Can Beijing's informal waste recycling sector survive amidst worsening circumstances? Resources, Conservation and Recycling, 128, 59-68.

http://dx.doi.org/10.1016/j.resconrec.2017.09.0 26

Steuer, B., Ramusch, R., Part, F., Salhofer, S., 2017. Analysis of the value chain and network structure of informal waste recycling in Beijing, China. Resources, Conservation and Recycling, 117 , 137-150. http://dx.doi.org/10.1016/j.resconrec.2016.11.0 07

Tirado-Soto, M.M., Zamberlan, F.L., 2013. Networks of recyclable material waste-picker's cooperatives: An alternative for the solid waste management in the city of Rio de Janeiro. Waste Management, 33(4), 1004-1012. https://doi.org/10.1016/j.wasman.2012.09.025

Uddin, S., Gutberlet, J., Ramezani, R., Nasiruddin, S., 2020. Experiencing the everyday of waste pickers: a sustainable livelihoods and health assessment in Dhaka City, Bangladesh. Journal of International Development. https://doi.org/10.1002/jid.3479

UN, 2018. United Nations Sustainable Development Goals. https://www.un.org/sustainabledevelopment/su stainable-development-goals/ (accessed 1th September 2018).

Vector, 2004. Plano de Gerenciamento Integrado de Resíduos Sólidos de Olinda, Volume I Diagnóstico da Situação Atual [Solid Waste Management Maste Plan of Olinda, Volume I Diagnosis of the current situation]. Recife: 2005. 
Revista Brasileira de Geografia Física, Vol. 13, n. 05 (2020) 1953-1969.

Wilson, D.C., Velis, C., Cheeseman, C., 2006. Role of informal sector recycling in waste management in developing countries. Habitat International $30 \quad$ (4), 797-808. https://doi.org/10.1016/j.habitatint.2005.09.005

Wilson, D., Rodic, L., Scheinberg, A., Velis, C.A., Alabaster, G., 2012. Comparative analysis of solid waste management in 20 cities Waste Waste Management \& Research 30(3) 237-
254.

https://doi.org/10.1177/0734242X12437569

Yu, D., Blaauw, D., Schenck, R., 2020. Waste pickers in informal self-employment: Overworked and on the breadline, Development Southern Africa, 1-26. https://doi.org/10.1080/0376835X.2020.17705 78 